\title{
Cytogenetic Characterization and NOR Polymorphism in Astyanax sp. C (Tetragonopterinae, Characidae) from the First Plateau of the Iguaçu River (Paraná State, Brazil)
}

\author{
Daniel Luis Zanella Kantek ${ }^{1}$, Alberto Sergio Fenocchio ${ }^{1,2}$ and \\ Marta Margarete Cestari $i^{1, *}$ \\ ${ }^{1}$ Universidade Federal do Paraná, Departamento de Genética, Laboratório de Citogenética Animal, \\ 81531-990 Curitiba, PR, Brazil \\ ${ }^{2}$ Universidad Nacional de Misiones, Departamento de Genética, Laboratório de Citogenética, \\ 3300-Posadas, Misiones, Argentina
}

Received October 30, 2002; accepted November 13, 2002

\begin{abstract}
Summary The characids belong to the greater freshwater fish family of the world with around 700 recognized species. Whithin this group the genus Astyanax includes several species with unclear phylogenetic relationships, showing a wide karyotypic diversity. In the highly endemic Iguaçu river basin these problems are also observed being distinguished 6 unnamed Astyanax species (A to F). In the present work were cytogenetically studied 2 populations of $A$. sp. C from the first plateau of the Iguaçu river (Paraná State, Brazil). Fishes of both populations are similar in chromosome number, having $2 n=50$, however were evidenced clear differences in C-banding and nucleolar organizing regions (NORs) patterns. With the use of the restriction enzyme Alu I were obtained the same results as C-bands. These results indicate the complexity of Astyanax and the importance of further taxonomic revisions joining morphological, cytogenetic and molecular approachings.
\end{abstract}

Key words Fish cytogenetics, Neotropical region, Characiformes.

Fishes of the family Characidae (Pisces, Characiformes) show a great diversity in shape, size and ecological features, being the largest group of fresh water from South America, performing around of 170 genera and 885 species (Nelson 1994).

Previous cytogenetic studies have demonstrated that some subfamilies of Characidae show almost conservative karyotypes, as is the case of Salmininae (Marco 1986) and Bryconinae (Vascon et al. 1984), and others present variable or "plastic" karyotypes generally associated with several taxonomic problems, as occurs in Serrasalmine (Arefjev 1990a, Cestari and Galetti Jr. 1992), Cheirodontinae (Arefjev 1990b, Wasko and Galetti Jr. 1994) and Tetragonopterinae (Portela et al. 1988, Arefjev 1990b).

The genus Astyanax (Tetragonopetinae) have shown a wide karyotypic variability, either in chromosome number and structure, being reported from $2 n=36$ in A. schubarti (Morelli et al. 1983 ) to $2 n=50$ in other species (Kirby et al. 1977, Souza and Moreira-Filho 1995). Variations in chromosome number also has being identified within some species of Astyanax, i.e. A. fasciatus (Morelli et al. 1983, Justi 1993, Heras 1998) and A. scabripinnis (Moreira-Filho 1989, MoreiraFilho and Bertollo 1991).

The Iguaçu river constitute an interesting area for biological studies because is divided in several "plateaus" separated by waterfalls that represent barriers, constituting a practically isolated system with a restricted and almost endemic fish fauna. Taxonomic studies in Astyanax from Iguaçu

* Corresponding author, e-mail: margaces@bio.ufpr.br 
river demonstrated that at least 6 different specific entities could be identified (Sampaio 1988), but only one have been named: $A$. gymnogenys (=A. sp. A), the others have named provisionally as Astyanax sp. B, C, D, E and F.

The objective of the present study was to characterize cytogenetically Astyanax sp. C from the first plateau of the Iguaçu river (Paraná State, Brazil) by means of conventional Giemsa staining and $\mathrm{C}, \mathrm{AgNOR}$ and RE bandings and compare the results with other available data.

\section{Materials and methods}

38 individuals of Astyanax sp. C from the first plateau of the Iguaçu river (Paraná State, Brazil) were studied at 2 localities, Sao José dos Pinhais (13 males, 18 females, 1 specimen of indetermined sex) and Piraquara (4 males, 2 females).

Chromosome preparations were obtained by direct methods (Bertollo et al. 1978) and by short term cultures of kidney cells (Fenocchio et al. 1991). NORs and C bandings were visualized respectively by Howell and Black (1980) and Sumner (1972) techniques. Restriction enzime (RE) banding were performed according Mezzanotte et al. (1983) with some modifications (Maistro 1996).

\section{Results and discussion}

The karyotype of Astyanax sp. C from the 2 populations are constituted by 2 pairs of metacentrics (M), 11 pairs of submetacentrics (SM), 4 pairs of subtelocentrics (ST) and 8 pairs of acrocentrics (A), summing $2 n=50$ and arm number (NF) $=84$ (Fig. 1). As is characteristic in other Characidae and Astyanax species, 2 large metacentric chromosomes constitute the first pair. Karyotypes of males and females from Sao José dos Pinhais (similar that those of Piraquara) are shown in Fig. 2. Heteromorphisms related to sex were not detected.

Individuals of the 2 popoulations show a secondary constriction at NOR sites on the short arm of one of the chromosomes of the pair 16 (Figs. 2A, 3D, E).

In Astyanax sp. C from Piraquara only one NOR bearing chromosome pair were observed, the bands were detected on the short arm of the pair 16 (Fig. 4B). C bands were scarce and the most conspicuous ones are associated with the NORs.

Specimens from Sao José dos Pinhais had multiple NORs and frequently showed associations. For instance, an NOR association between 3 and 16 chromossomes, shown in the Fig. 3 (A, B). The number of NORs bearing chromosomes varied from 1 to 4 per metaphase plate (Fig. 4A). A total of 8 non-homologous chromosomes beared NORs (Fig. 4B-G). In the sample of Sao Jose dos Pinhais a SM chromosome showing a interstitial secondary constriction on the long arm were detected and it is also related to NORs (Figs. 3C, 4C).
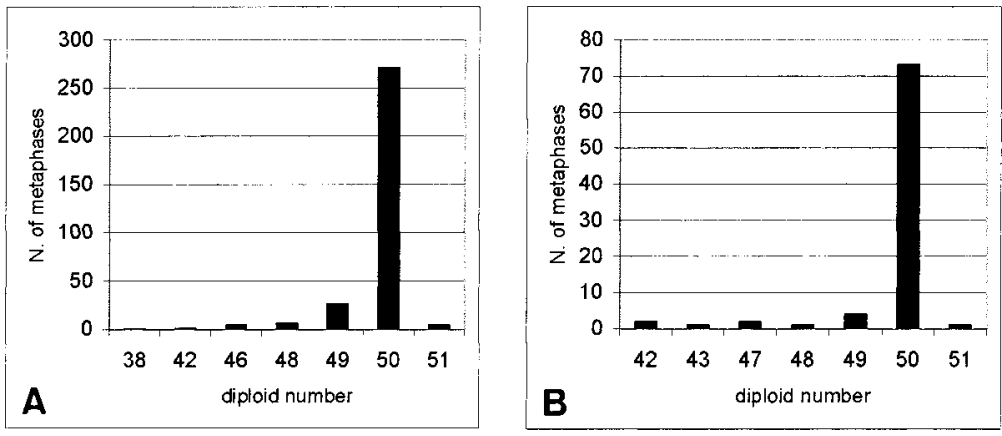

Fig. 1. Frequencies of diploid numbers of the studied specimens from: A) Sao José dos Pinhais and B) Piraquara. 


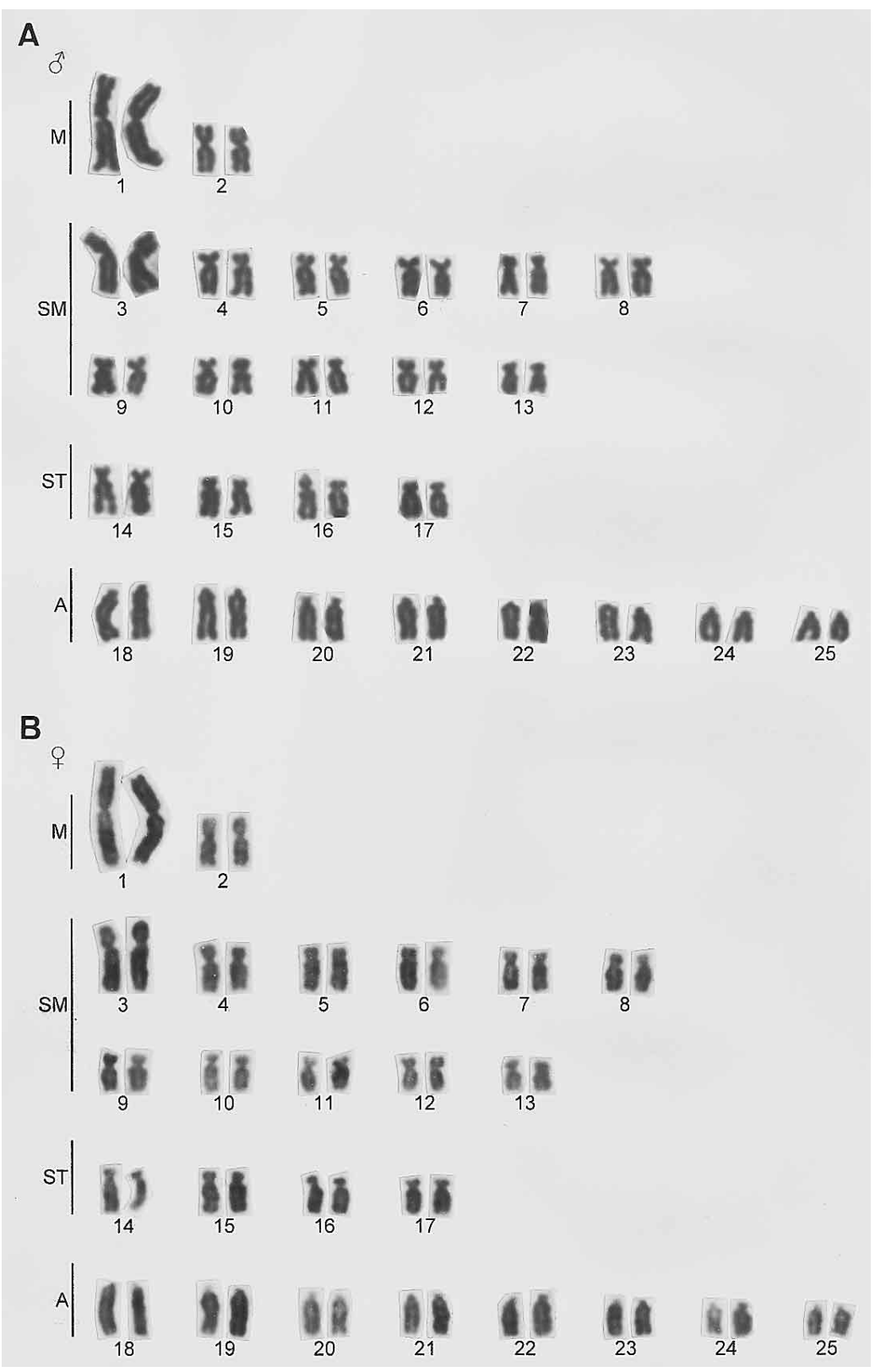

Fig. 2. Karyotypes of males (A) and females (B) of Astyanax sp. C from Sao José dos Pinhais.

Only chromosomes of the pair 16 always showed silver impregnation at their decondensed secondary constriction (Fig. 3E). The other silver positive bands had a high intra- and inter-individual variation, either in number and location. In some individuals a strong band was detected on the short arm of one of the homologues of the third chromosome pair (Figs. 3A, B, 4B).

The C-bands of Astyanax sp. C from Sao José dos Pinhais showed a wide polymorphic variation and were coincident with the NORs (Figs. 3D, E, 5A, B). Centromeric bands were pale and only apparent in decondensed chromosomes (Fig. 5B), also some telomeric bands on the acrocentric chromossomes ( $\mathrm{p}$ arm) were detected.

When restriction enzimes are applied to several fish species the band pattern was generally like 

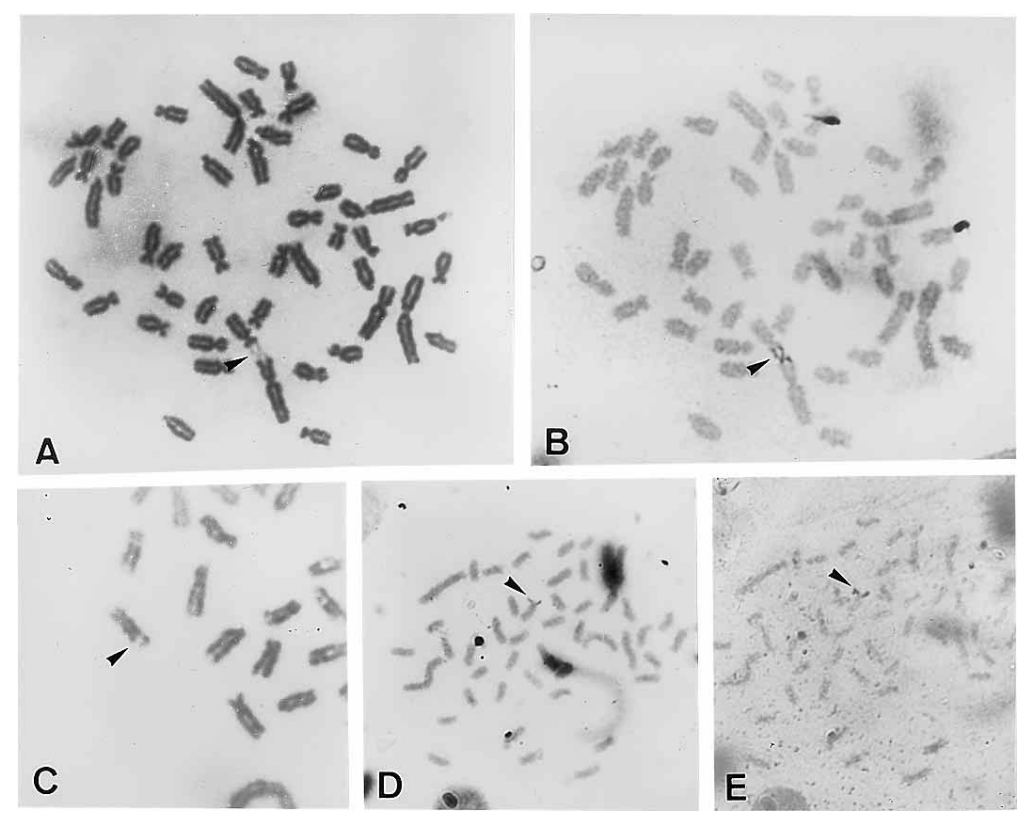

Fig. 3. Metaphase plates of $A$. sp. C from Sao José dos Pinhais. A, B) sequential Giemsa- $\mathrm{AgNO}_{3}$ staining showing a secondary constriction and chromosome association; C) Giemsa staining, the arrowhead indicates a secondary constriction related to NORs; D, E) sequential staining C-band and $\mathrm{AgNO}_{3}$.
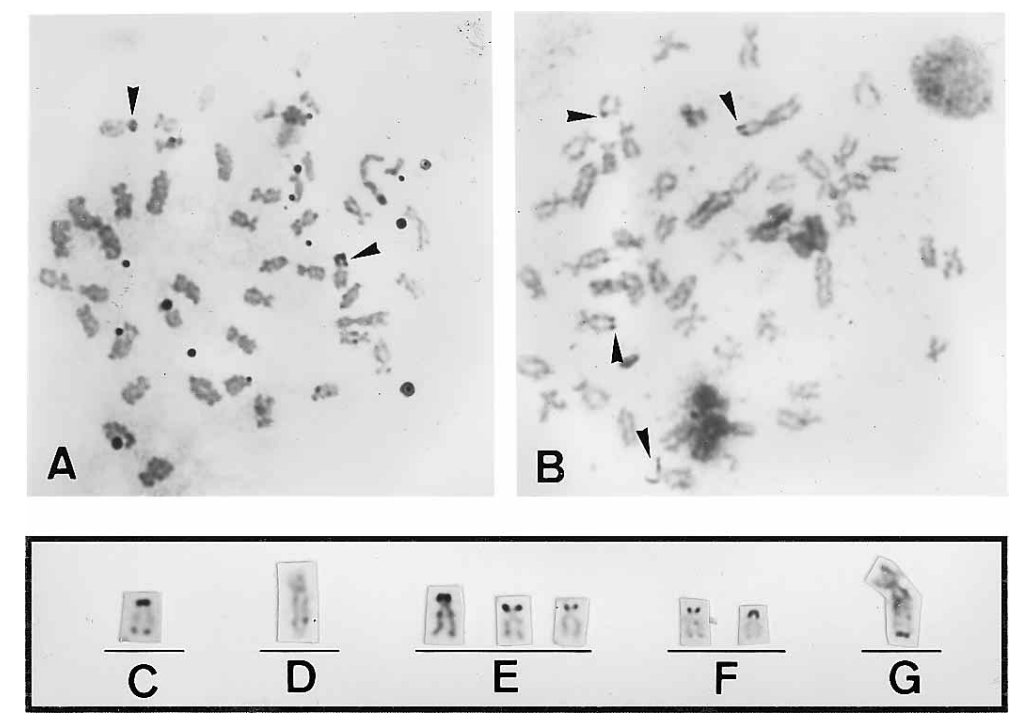

Fig. 4. Astyanax sp. C, $\mathrm{AgNO}_{3}$ staining. A) Piraquara population, single NORs; B-G) Sao José dos Pinhais, multiple NORs; in the box, several NOR bearing chromosomes.

the C banding (Maistro et al. 1999, Swarça et al. 1999). The digestion with Alu I in the chromosome preparations from Sao José dos Pinhais showed a staining pattern almost similar to the C banding, with a strong Giemsa staining on the NORs secondary constrictions and heterochromatic regions (Fig. 5C).

In spite of the karyotypic diversity of the family Characidae, several species and populations of the genus Astyanax shared some basic cytogenetic traits i.e. the diploid number $(2 n=50)$ and a 

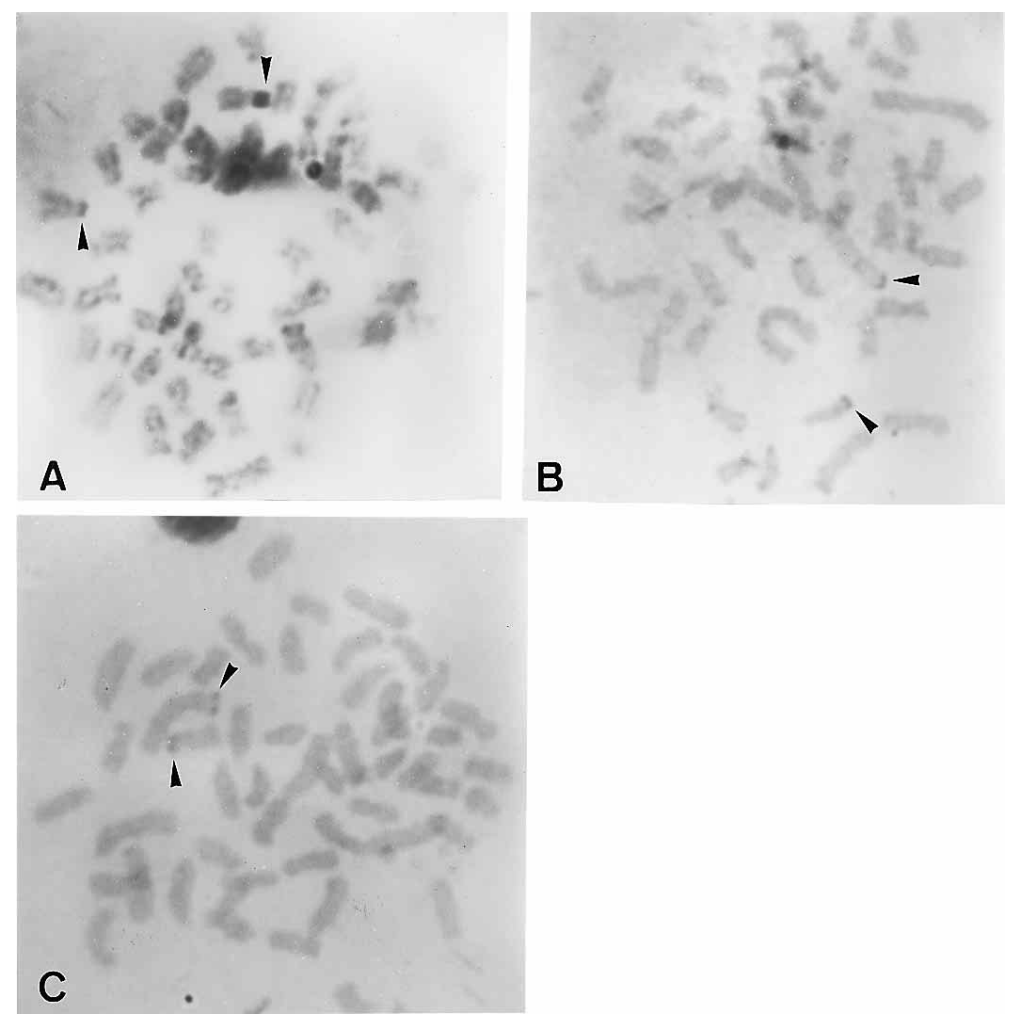

Fig. 5. Metaphase plates of Astyanax sp. C from Sao José dos Pinhais. A, B) C-banding; C) Alu I digestion.

large first metacentric pair, as observed in A. bimaculatus (Scheel 1973, Paganelli and Galetti Jr. 1986), A. taeniatus (Rocon-Stange et al. 1986) and A. eigenmanniorum (Fauaz et al. 1994).

Similarly, Astyanax sp. C of the 2 populations studied here presents these features, but some differences could be pointed between them in relation to the number of NOR bearing chromosomes, only 1 pair in Piraquara and multiple NORs in Sao José dos Pinhais. Likewise, the C-bands were different among these populations, being polymorphic in Sao José dos Pinhais and monomorphic in the individuals from Piraquara, that showed a single C-band pattern.

The absence of conspicuous and larger heterochromatic blocks distinguishes Astyanax sp. C from other species of the genus and this trait would be considered a marker character.

These data represent the first contribution to the cytogenetic knowledge of the complex genus Astyanax in the Iguaçu river and further works joining diverse approaches (cytogenetic, molecular, morphologic) about the other related species (A. sp. A, B, D, E, F) would help to clarify their systematic relationships.

\section{References}

Arefjev, V. A. 1990a. Karyotypic diversity of characid families (Pisces, Characidae). Caryologia 43: 291-304.

- 1990b. Problems of Karyotypic variability in the family Characidae (Pisces, Characiformes) with the description of somatic karyotypes for six especies of tetras. Caryologia 43: 305-319.

Bertollo, L. A. C., Takahashi, C. S. and Moreira-Filho, O. 1978. Cytotaxonomic considerations of Hoplias lacerdae (Pisces, Erythrinidae). Brazil. J. Genet. 1: 103-120.

Cestari, M. M. and Galetti Jr., P. M. 1992. Chromossome studies of Serrasalmus spilopleura (Characidae, Serrasalminae) from de Paraná-Paraguai rivers: evolutionary and cytotaxonomic considerations. Copeia 1: 108-112. 
Fauaz, G., Vicente, V. E. and Moreira-Filho, O. 1994. Natural Triploidy and B chromosomes in the neotropical fish genus Astyanax (Characidae). Brazil. J. Genet. 17: 157-163.

Fenocchio, A. S., Venere, P. C., Cesar, A. C. G., Dias, A. L. and Betollo, L. A. C. 1991. Short term culture from solid tissues of fishes. Caryologia 44: 161-166.

Heras, M. P. 1998. Estudos citogenéticos em Astyanax fasciatus (Pisces, Characidae) de alguns rios do Brasil. Master thesis. Univ. Federal de São Carlos (São Carlos, SP, Brazil).

Howell, W. M. and Black, D. A. 1980. Controlled silver-staining of nucleolus organizer regions with a protective colloidal developer: a 1-step method. Experientia 36: 1014-1015.

Justi, A. J. 1993. Caracterização cariotípica de populações de Astyanax fasciatus (Cuvier, 1819), Pisces, Characidae, em três bacias hidrográficas. Master's thesis. Univ. Federal de São Carlos (São Carlos, SP, Brazil).

Kirby, R. F., Thompson, K. W. and Hubbs, C. 1977. Karyotypic similarities between the mexican and blind tetras. Copeia 3: $578-580$.

Maistro, E. L. 1996. Caracterização morfológica e estrutural de cromossomos supranumerários em peixes. Doctoral thesis. Universidade Estadual Paulista (Botucatu, SP, Brazil).

-, Foresti, F. and Oliveira, C. 1999. R- and G-Band Patterns in Astyanax scabripinnis paranae (Pisces, Characidae, Characiformes). Genet. Mol. Biol. 22: 201-204.

Marco, D. A. 1986. Estudos cromossômicos em peixes da subfamilia Salmininae (Pisces, Characidae). Master's thesis. Univ. Federal de São Carlos (São Carlos, SP, Brazil).

Mezzanotte, R., Bianchi, U., Vanni, R. and Ferruci, L. 1983. Chromatin organization and restriction endonuclease activity on human metaphase chromosomes. Cytogenet. Cell Genet. 36: 562-566.

Moreira-Filho, O. 1989. Analises cariotípicas e morfológicas sobre a diversidade no "complexo" Astyanax scabripinnis (Pisces, Characidae, Tetragonopterinae). Doctoral thesis. Univ. Federal de São Carlos (São Carlos, SP, Brazil).

— and Bertollo, L. A. C. 1991. Astyanax scabripinnis (Pisces, Characidae): a species complex. Brazil J. Genet. 14: 331-357.

Morelli, S., Bertollo, L. A. C., Foresti, F., Moreira-Filho, O. and Toledo-Filho, S. A. 1983. Cytogenetic considerations on the genus Astyanax (Pisces, Characidae). I. Kariotypic variability. Caryologia 36: 235-244.

Nelson, S. J. 1994. Fishes of the World. (3rd ed.). John Wiley \& Sons, New York.

Paganelli, H. H. and Galetti Jr., P. M. 1986. Analise cariotípica nos gêneros Probolodus e Astyanax (Pisces, Characidae). Proc. I Simp. Citog. Evol. Aplic. de Peixes Neotropicais, p. 53.

Portela, A. L. B. S., Galetti Jr., M. and Bertollo, L. A. C. 1988. Considerations on the chromossome evolution of Tetragonopterinae (Pisces, Characidae). Brazil. J. Genet. 11: 307-316.

Rocon-Stange, E. A., Silva, V. E. and Dutra, S. V. 1986. Citogenética do gênero Astyanax (Pisces, Characidae) nas bacias dos rios Benevente e Jucu. Proc. I Simp. Citog. Evol. Aplic. de Peixes Neotropicais, p. 53.

Sampaio, F. A. A. 1988. Estudos taxonômicos preliminares dos Characiformes (Teleostei, Ostariophysi) da Bacia do Rio Iguaçu, com comentários sobre o endemismo desta fauna. Master’s thesis. Univ. Federal de São Carlos (São Carlos, SP, Brazil).

Scheel, J. J. 1973. Fish Chromosomes and Their Evolution. Charlottenlund, Denmark. Internal Report of Danmarks Akvarvum. p. 22.

Souza, I. L. and Moreira-Filho, O. 1995. Cytogenetic diversity in the Astyanax scabripinnis species complex (Pisces, Characidae). I. Allopatric distribution in a small stream. Cytologia 60: 1-11.

Sumner, A. T. 1972. A simple technique for demonstrating centromeric heterochromatin. Expl. Cell Res. 74: 304-306.

Swarca, A. C., Caetano, L. G. and Dias, A. L. 1999. Cytogenetic characterization through chromosomic banding of Pinirampus pirinampu (Pisces, Pimelodidae) from the Tibagi river basin PR/Brasil. Caryologia 52: 31-35.

Vascon, S. A., Pileggi, N. and Moreira-Filho, O. 1984. Estudos citogeneticos em Brycon lundii (Pisces, Characidae). Cienc. Cult. 36(Supl.): 813.

Wasko, A. P. and Galetti Jr., P. M. 1994. Citogenética de pequenos peixes caracideos do grupo Cherodontinae. Cromossomos mitóticos de Odontostilbe paranensis, O. claudiae e Holoshestes heterodon. Brazil J. Genet. 17: 122 (supplement). 